\title{
NATURAL AND HUMAN-INDUCED SUBSIDENCE DUE TO GYPSUM DISSOLUTION: A CASE STUDY FROM INANDIK, CENTRAL ANATOLIA, TURKEY
}

\author{
Ergin Gökkaya ${ }^{1, C}$ and Esra Tunçel ${ }^{2}$
}

\begin{abstract}
Gypsum dissolves relatively quickly and gypsum karst can evolve on a rapid time scale that may be accelerated by human-induced change, often resulting in severe subsidence damage. The area close to Inandık stream in Central Anatolia, Turkey, is affected by subsidence in two ways: formation of collapse sinkholes on agricultural land and progressive subsidence in Inandık village that has damaged buildings. This study focuses on these subsidence phenomena. Seven large sinkholes were formed on a terrace where episodic incision of the fluvial system has led to reduced thickness and mechanical strength of the cavity roof; a process that also increases the hydraulic gradient and enhances cavity development in the terrace area. These processes formed a sinkhole-prone terrace surface. The other subsidence phenomena, which have increased progressively in the last decade, relate to human activity in Inandık village. Water consumption increased after domestic water service systems were installed in houses in 2007, and in 2012 a sewer system was built in the village. Due to cracks and breakage, leaking water from buildings and sewer pipes infiltrated the gypsum substratum, resulting in dissolution of the bedrock and superficial cavity formation, as shown by GPR and borehole data. The process leading to subsidence caused severe damage to buildings. Consequently, it was decided to relocate the village three $\mathrm{km}$ south of its current location because of the high level of damage.
\end{abstract}

\section{Introduction}

Gypsum has a high dissolution rate that is greater than carbonate rocks (Klimchouk et al., 1996; Martinez et al., 1998); therefore, gypsum karst can evolve at a much faster rate (Benito et al., 1995; Cooper and Saunders, 2002; Gutiérrez and Cooper, 2013; Gutiérrez et al., 2014; De Waele et al., 2017) and be further accelerated by human-induced changes. Such high solubility leads to problems, the most frequent of which is subsidence, thereby threatening property. The subsidence hazard has been observed in various countries with gypsum karst terrain (Sauro, 1996; Jassim et al., 1997; Cooper, 1998; Paukštys et al., 1999; Cooper and Saunders, 2002; Klimchouk and Andrejchuk, 1996, 2002; Delle Rose et al., 2004; Johnson, 2005; Parise and Trocino, 2005; Gutiérrez et al., 2008; Koutepov et al., 2008; Parise et al., 2004, 2009; Thierry et al., 2009; Del Prete et al., 2010; lovine et al., 2010; Cooper and Gutiérrez, 2013; Gutiérrez and Cooper, 2013; Gutiérrez, 2016; Calligaris et al., 2017). In Oviedo (Spain), subsidence due to gypsum dissolution led to the demolition of 362 flats at a loss of 18 million euro (Pando et al., 2012). Many buildings in Calatayud (Spain) have also been affected by subsidence and some of them had to be demolished due to the extent of the damage (Gutiérrez and Cooper, 2002; Gutiérrez, 2014).

Turkey has extensive gypsum outcrops in the provinces of Sivas and Çankırı (Fig. 1a). Despite the importance of gypsum karst, there are only a limited number of studies aimed at understanding the karstification of gypsum and related problems caused by subsidence. Although gypsum karst studies have been carried out in the Sivas region (Alagöz, 1967; Karacan and Yılmaz, 1997; Günay, 2002; Waltham, 2002; Doğan and Yeşilyurt, 2004; Doğan and Özel, 2005; Yilmaz, 2007; Keskin and Yılmaz, 2016) there has been no research on karst features and related hazards in the Çankırı region, except on some fossil subsidence sinkholes east of Çankırı (Doğan, 2002).

The area encompassing Inandık stream in the south of Çankırı province (Fig. 1b) has been influenced both by progressive subsidence in Inandık village, causing damage to buildings, and the formation of collapse sinkholes on agricultural land (Fig. 1c). This study deals with the triggering factors and their relationship with subsidence hazards in the area, as well as examining the origin of the collapse sinkholes. To our knowledge, the case of Inandık is the first published example of building damage due to gypsum dissolution in Turkey. The results of this study will contribute to understanding the controlling factors of subsidence mechanisms in this country and other gypsum karst areas.

\section{Materials and Methods}

The subsidence phenomena were analyzed by geological, geomorphological, and geophysical data. To detect buried collapse sinkholes and their period of generation, multiple sets of aerial photographs $(1953,1956,1971,1990$, and 2008), orthophotos and satellite images from 2010 and 2016 were used. The importance of multi-temporal analysis for

\footnotetext{
${ }^{1}$ Department of Geography, Ankara University, 06100 Ankara, Turkey

${ }^{2}$ Department of Geography, Bilecik Şeyh Edebali University, 11230 Bilecik, Turkey

${ }^{\mathrm{c}}$ Corresponding author: erginngokkaya@gmail.com
} 

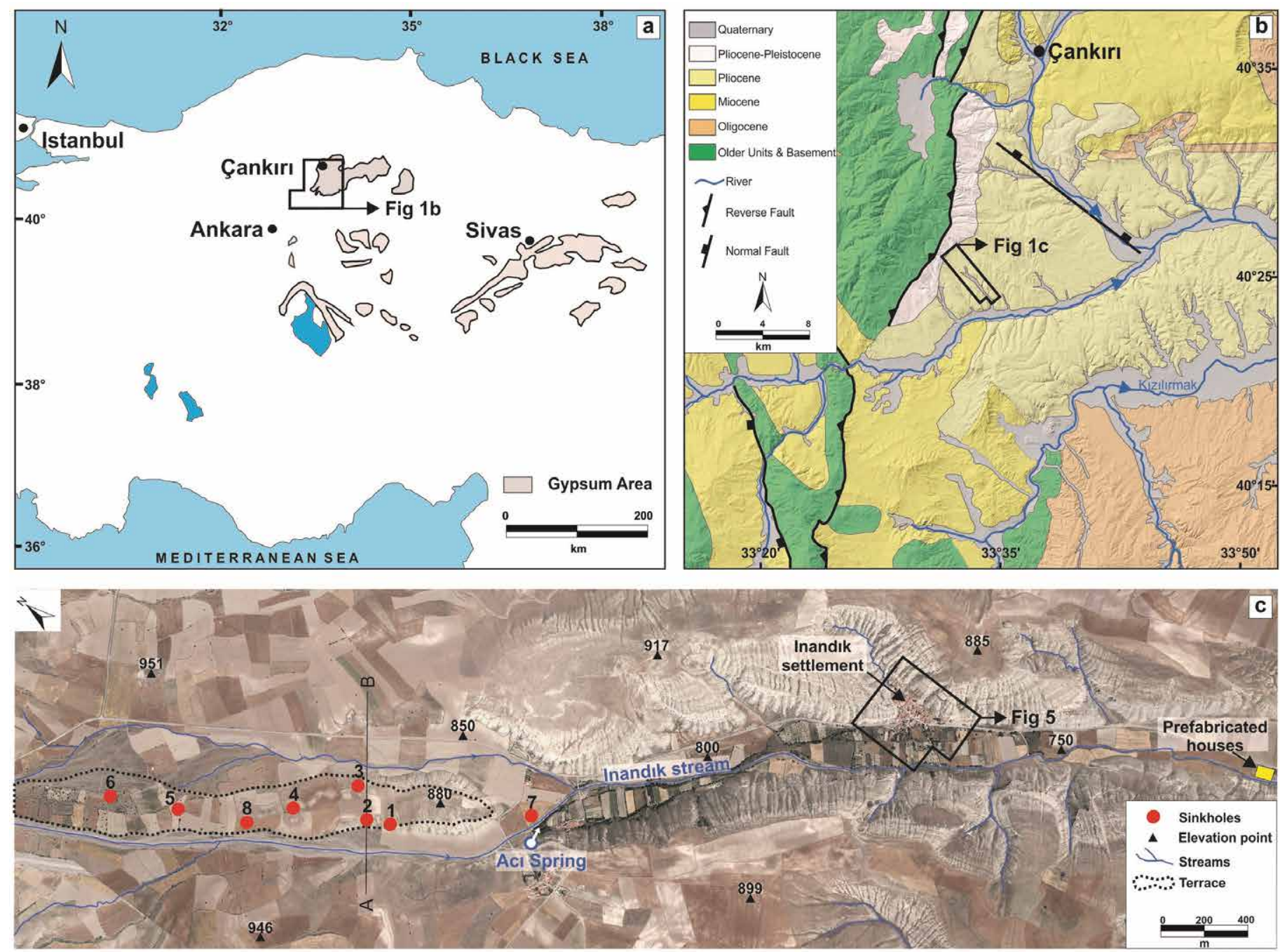

Figure 1. (a) Map showing location of study area. (b) Distribution of evaporite outcrops in study area and surroundings (modified from Karadenizli 2011). (c) Inandık village and vicinity.

understanding the evolution process of sinkholes has been stated on several occasions (Delle Rose and Parise, 2002; Festa et al., 2012; Basso et al., 2013; Calligaris et al., 2017).

Furthermore, the Turkish Disaster and Emergency Management Authority (AFAD) examined the village by digging boreholes and using high resolution near-subsurface imaging with ground penetrating radar (GPR). Images were obtained using a GSSI SIR 3000 portable device fitted with a $270 \mathrm{MHz}$ antenna (Özçelik et al., 2016). For this study, we utilized the AFAD data and also produced a map showing the distribution of subsidence susceptibility. In addition, useful information on current subsidence in the settlement and sinkhole formation was obtained from local residents.

\section{Background}

The Çankırı region is located in the Çankırı-Çorum sedimentary basin (Fig. 1a). The basin experienced evaporite formation in the Oligocene, Late Miocene, and Pliocene reaching $7500 \mathrm{~m}$ in thickness (Karadenizli, 2011). Lacustrine Pliocene evaporites and the Bozkır Formation crop out around the study area (Fig. 1b). This evaporitic sequence has a thickness of up to $750 \mathrm{~m}$ and 60-100 m thick gypsum levels intercalated by mudstone, selenite, clayey limestone (Karadenizli, 2011) and salt, anhydrite and glauberite (Sönmez, 2014). Karst subsidence in the study area is linked to the dissolution of Pliocene evaporites.

The Kızlırmak drainage system developed in the basin at the beginning of the Quaternary, leading to closure of the basin. Karstification of gypsum and subsidence phenomena began when Pliocene evaporites were downcut by the Kızılırmak drainage system and overlain by loose alluvial deposits. The episodic downcutting of Inandık stream and its tributary in the study area generated a terrace $15 \mathrm{~m}$ above stream level and $25 \mathrm{~m}$ below adjacent ridges. The terrace is located northwest of Inandık village and its surface is overlain by alluvium 0 to $6 \mathrm{~m}$ thick (Fig. 1c). 
The vicinity of Inandık has a semi-arid climate with a mean annual rainfall of $400 \mathrm{~mm}$. Average temperatures range from $-0.9^{\circ} \mathrm{C}$ in January to $23.1^{\circ} \mathrm{C}$ in July. Inandık stream, fed by karst springs, does not flow during the summer. The $\mathrm{Acl}$ (bitter) Spring, so named because it contains dissolved calcium sulfate, emerges from cavities in the gypsum at the point where the spring waters join Inandık stream.

The village was founded in the 19th century and contains 68 buildings that were mainly constructed in the first half of the 20th century. By 2015, most dwellings in the village were in poor condition due to damage from subsidence in the last decade. The most recent collapse sinkhole to be formed on agricultural land occurred in 2012. For these reasons, the inhabitants of Inandık applied to AFAD in 2015 for assistance to try and solve their problems.

After the investigation by AFAD was completed (Özçelik et al., 2016), the government decided to relocate the village three $\mathrm{km}$ south of its current location at a cost of 2 million euro because of the collapse threats. The provincial governorship has installed and allocated 72 prefabricated houses for temporary use until the village is moved (Fig. 1c). Once construction of the new village is complete, the residents will be permanently moved to the new location. Currently, the prefabricated houses are unoccupied and some residents of Inandık continue to live in the old village.

\section{Sinkholes}

Sinkholes are closed depressions typical of karst terrain. A significantly-sized cavity is necessary for the formation of bedrock collapse and caprock collapse sinkholes (e.g., Waltham et al., 2005; Gutiérrez et al., 2014, 2019). Other types of sinkholes, such as the cover-collapse sinkhole, may occur in the presence of limited-size cavities and voids (e.g., Gutiérrez, 2016). Cover-collapse sinkholes result from the upward propagation of cover failure, leading to the collapse of the overburden. This type of sinkhole is responsible for most sinkhole hazards around the world (Waltham et al., 2005; Parise, 2010; Gutiérrez et al., 2014). Their detection is made difficult because they are easily buried by farmers due to their relatively small size and depth. Analysis of historical documentation such as topographic maps, old pictures and images is therefore useful for detecting these sinkholes. Moreover, the data obtained can provide insights into their spatial and temporal distribution, as experienced with other types of natural hazards, such as landslides (Parise and Wasowski, 1999; Calcaterra and Parise, 2001; Pisano et al., 2017).

To detect the sinkholes in the current study, aerial and satellite images were compared and eight collapse sinkholes were identified northwest of Inandık. These were numbered according to their date of formation (Fig. 1c, Table 1). Five of them existed before 1953. Except for sinkhole 7, that is the smallest, all the sinkholes are clustered on the river terrace. Local residents reported that sinkholes smaller than a meter in diameter, similar to sinkhole 7 , had been found in the valley bottom, but were buried. These cannot be detected in aerial photographs because of their size and having been filled in soon after formation.

Sinkhole 2 (Fig. 2a) is the largest with a diameter of $44 \mathrm{~m}$ and depth of $22.5 \mathrm{~m}$ at an altitude of $877 \mathrm{~m}$ a.s.l. It is the only bedrock collapse sinkhole and was formed before 1953. Blocks were observed in its bottom and many fractures are visible around the sinkhole, indicating that it has enlarged due to mass wasting. This sinkhole in particular shows that large cavities exist under the terrace.

Sinkhole 7 was formed between 1990 and 2008 at an altitude of $832 \mathrm{~m}$ a.s.l. This cover-collapse sinkhole was detected in the valley bottom and is relatively small and shallow, with a diameter of $1 \mathrm{~m}$ and depth of $1 \mathrm{~m}$.

The most recent sinkhole is number 8 (Fig. 2b), formed in 2012. It is $13 \mathrm{~m}$ in diameter and somewhat enlarged since traces of erosion are visible at its margins, and is $10 \mathrm{~m}$ deep. The depth of the sinkhole is $5 \mathrm{~m}$ greater than the thickness of the alluvial deposit. It is classified as a cover-collapse sinkhole.

The other sinkholes can only be observed in some of the aerial photographs. They have now disappeared because farmers have filled them, canceling the surface features (Fig. 2c, d, e). These buried sinkholes can also be defined as

Table 1. Measurements, age, and type of sinkholes detected at Inandık.

\begin{tabular}{cccccc}
\hline $\begin{array}{c}\text { Sinkhole } \\
\text { Number }\end{array}$ & $\begin{array}{c}\text { Formation } \\
\text { Period }\end{array}$ & Altitude $\mathbf{( m )}$ & Diameter $(\mathbf{m})$ & Depth $\mathbf{( m )}$ & Genetic Type \\
\hline 1 & Before 1953 & 877 & $\ldots$ & $\ldots$ & Buried sinkhole \\
2 & Before 1953 & 882 & 44 & 22.5 & Bedrock Collapse sinkhole \\
3 & Before 1953 & 881 & 5 & $\ldots$ & Buried sinkhole \\
4 & Before 1953 & 886 & 12 & $\ldots$ & Buried sinkhole \\
5 & Before 1953 & 916 & 7 & $\ldots$ & Buried sinkhole \\
6 & $1953-1971$ & 927 & 1 & $\ldots$ & Buried sinkhole \\
7 & $1990-2008$ & 832 & 13 & 1 & Cover collapse sinkhole \\
8 & 2012 & 898 & & 10 & Cover collapse sinkhole \\
\hline
\end{tabular}



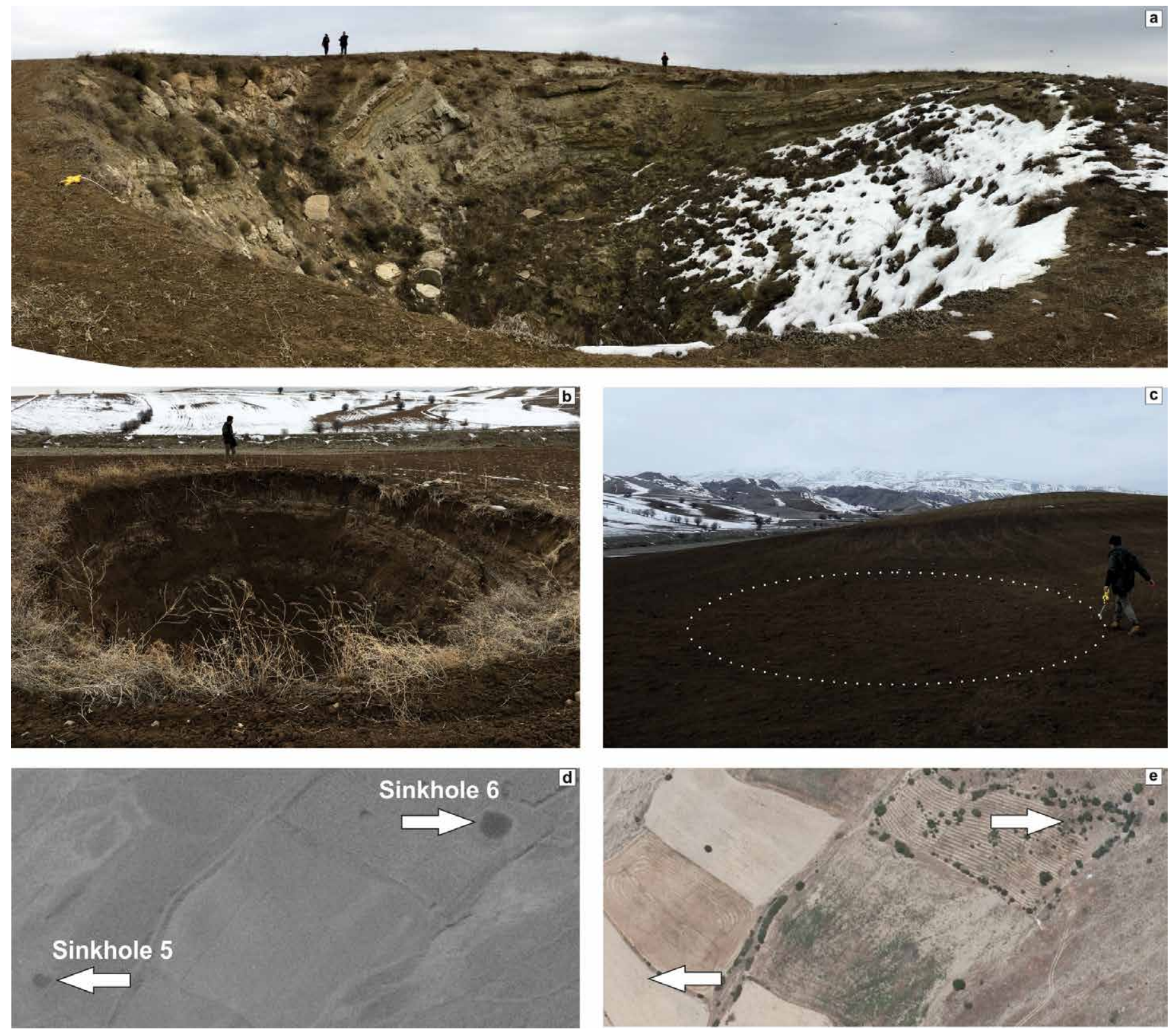

Figure 2. (a) Panoromic view of Sinkhole 2, the deepest and largest sinkhole in study area. Note separated blocks on the sides. (b) Sinkhole 8 , most recent sinkhole in study area. (c) Sinkhole 4 , buried by farmers. Soil containing small white pebbles brought from elsewhere mark the sinkhole within the boundary indicated. (d) Historical aerial photograph of sinkholes 5 and 6 . (e) Recent view of buried sinkholes 5 and 6.

cover-collapse sinkhole because they formed in alluvial deposits.

Existing sinkholes are the predictors of future sinkhole formation. Regarding the spatial distribution of the eight sinkholes, they are clustered in a line of about $0.3 \mathrm{~km}^{2}$ along the NW-SE $1.9 \mathrm{~km}$ alignment. This area offers the highest probability for formation of new sinkholes.

\section{Subsidence in the village}

Inandık village is situated in a tributary valley on the eastern flank of Inandık stream with the SW part of the village within the main valley (Fig. 1c). There is no streamflow in the valley bottom since precipitation falling in the area surrounding the village in the rainy season is drained underground. The recharge to Inandık stream includes discharge from Inandık settlement which, we believe, has enhanced dissolution of the bedrock, as documented on paleo-subsidence structures (Fig. 3) which can be observed in many gypsum bedrock outcrops in the village, providing us with data about recent subsidence events. They also demonstrate that subsidence phenomena have been occurring over a long period. In support of this, information from inhabitants and local authorities indicate that the village has been affected by subsidence and sinkholes for generations. Although some damage occurred in the past, the frequency of subsidence events has in- 


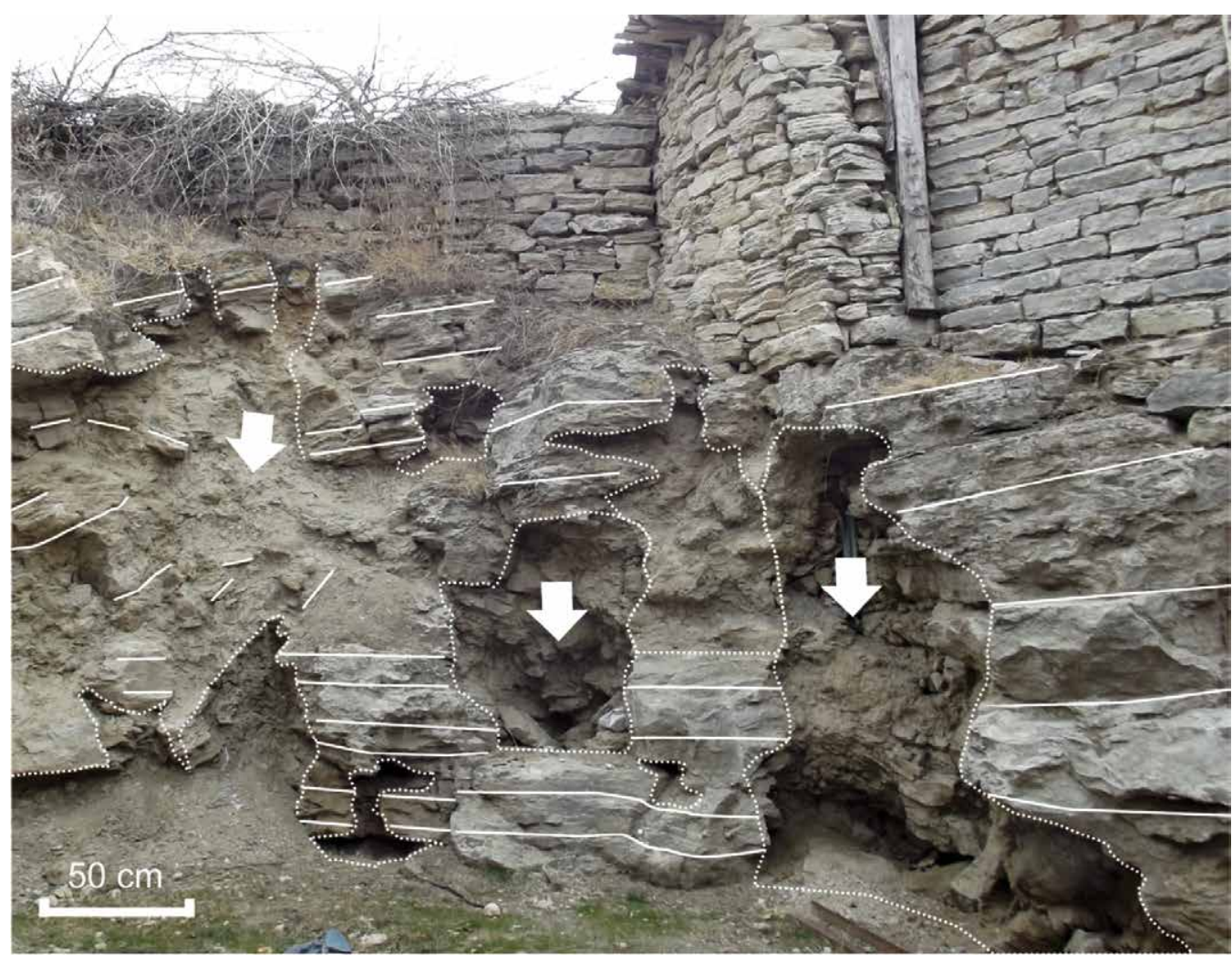

Figure 3. Paleo-subsidence structures in gypsum bedrock. Cavities are filled with karstic residue and gypsum blocks. (Photograph taken on eastern slope of village). which show open fractures and tilted, cracked walls (Fig. 4). Moreover, some of the buildings are very old; therefore they are severely affected by even the slightest subsidence. Several have been demolished because the damage was beyond repair.

We received information from the local authority that the water consumption habits of the inhabitants had changed recently, which has most likely affected the karst system. There was limited water consumption previously in the village but usage increased significantly after in-house water was provided in 2007 . The total annual water consumption of the inhabitants reached 118.7 tons in 2015. Around the same time, in 2012 a sewage system was installed in the village. However, some buildings still channel wastewater directly into the ground (Fig. 4b) due to badly-designed drains. Information from the local authority and inhabitants also suggests that the service and sewage pipes crack quite often. Such leaks result in a large amount of water seeping into the karst system in the village.

\section{Spatial distribution of damage}

Subsidence damage is caused by several factors including landslides, karst subsidence, and mining-induced subsidence. Land movement tends to be predominantly downward in coal mining and active karst subsidence areas, whilst a combination of downward and outward movement is typically observed in landslide areas (Cooper, 2008). Such movements cause damage to man-made structures and economic loss. Determining the degree and spatial distribution of the damage is necessary to understanding the subsidence mechanism. Therefore, several schemes have been generated to assess the damage to buildings (Cooper, 2008). The National Coal Board (NCB) (1975) in the UK created five categories for defining damage in coal mining areas (Cooper and Calow, 1998). Alexander (1986) and Chiocchio et al. (1997) developed a landslide damage classification of seven categories with two extra more severe damage categories but which otherwise closely resembles the NCB scheme. To determine the distribution of the subsidence hazard on gypsum karst, the NCB categories were adapted by Gutiérrez and Cooper (2002).

Buildings were assessed in the present study according to the categories of the NCB (1975) and Gutiérrez and Cooper (2002). Three category levels were used (Table 2) and a damage map showing the spatial distribution of the subsidence was generated (Fig. 5). This method has limitations because the internal damage to buildings was not assessed; moreover, the cause of damage could be related to other factors such as age or building materials. However, buildings in the village that are similar to each other exhibit no signs of damage. Relatively new structures constructed in the last 15 years also appear to be more resistant to subsidence and were evaluated separately on the map (Fig. 5). 

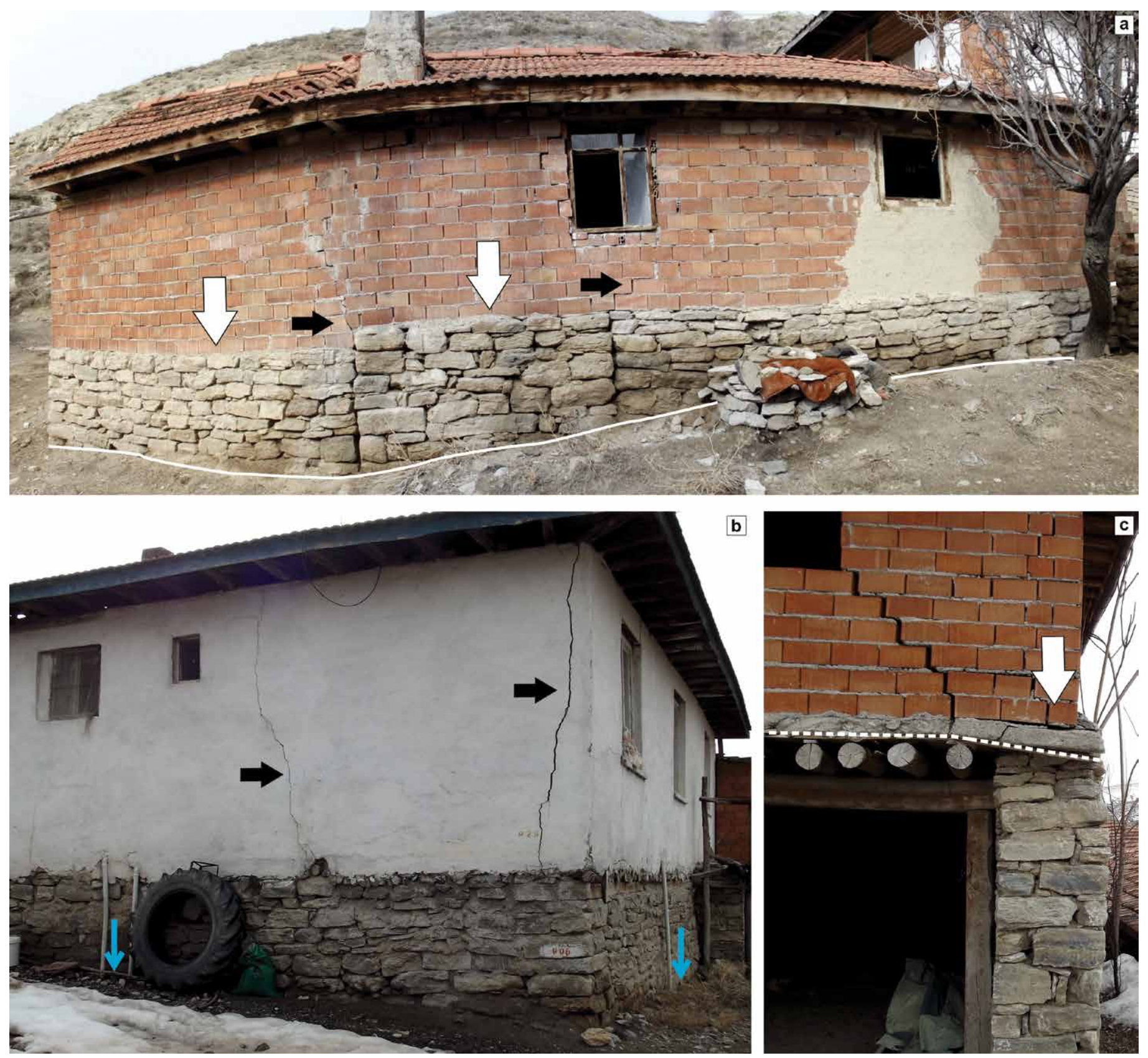

Figure 4. (a) Displacement of house wall showing bulging and cracking caused by subsidence, and broken windows due to distortion. (b) Cracks on wall and pipes draining wastewater directly into ground. (c) Open joint in wall of building. (Photographs taken on February 26 , 2017).

The map shows that most of the damage is concentrated at the bottom of small tributary valleys, whilst structures located in the main valley experienced no damage.

\section{Ground penetrating radar (GPR) and bore- hole data}

Five GPR profiles with a total length of $565 \mathrm{~m}$ (Fig. 5) were obtained from the settlement area (Özçelik et al., 2016). Profile 1 (Fig. 6a) mostly concentrates on the in-house and sewage water pipelines and shows shallow and relatively deep anomalies. Shallow anomalies between 20 and $32 \mathrm{~m}$, and between 55 and $70 \mathrm{~m}$ are observed at a depth of $1-$
$10 \mathrm{~m}$. These reflections with different dips in this profile are likely related to sagging structures. Relatively deep anomalies are also observed $20 \mathrm{~m}$ and $40 \mathrm{~m}$ from the beginning

Table 2. Categorization of damage to structures in Inandık village (Gutiérrez and Cooper 2002, and references therein).

Category $\quad$ Typical Damage

No Damage

Appreciable

Hairline cracks, several slight fractures (millimetric), doors and windows may stick slightly.

Severe Open fractures, window and door frames distorted requiring partial or complete reconstruction, displaced tilted walls. 
of the profile at a depth of 50-100 m. Profile 5 (Fig. 6b) focuses on the area northwest of the village. It shows anomalies located from the beginning of the profile at 10,20 , and $30 \mathrm{~m}$ and having a depth from 10 to $100 \mathrm{~m}$. Shallow anomalies at $10 \mathrm{~m}$ and $25 \mathrm{~m}$ along the profile show a sagging structure. These anomalies seen on profiles 1 and 5 probably correspond to fractures, cavities, and sagging structures near the surface in the gypsum bedrock (Fig. 6a, b). Profile 1, located below the most damaged area, shows several anomalies more than profile 5, and both the anomalies and damaged buildings decrease towards the end of profile 5 . These observations are compatible with the spatial distribution of the damage. Although the effect of subsidence was observed in structures near the other three profiles (Fig. 5), anomalies were not de-

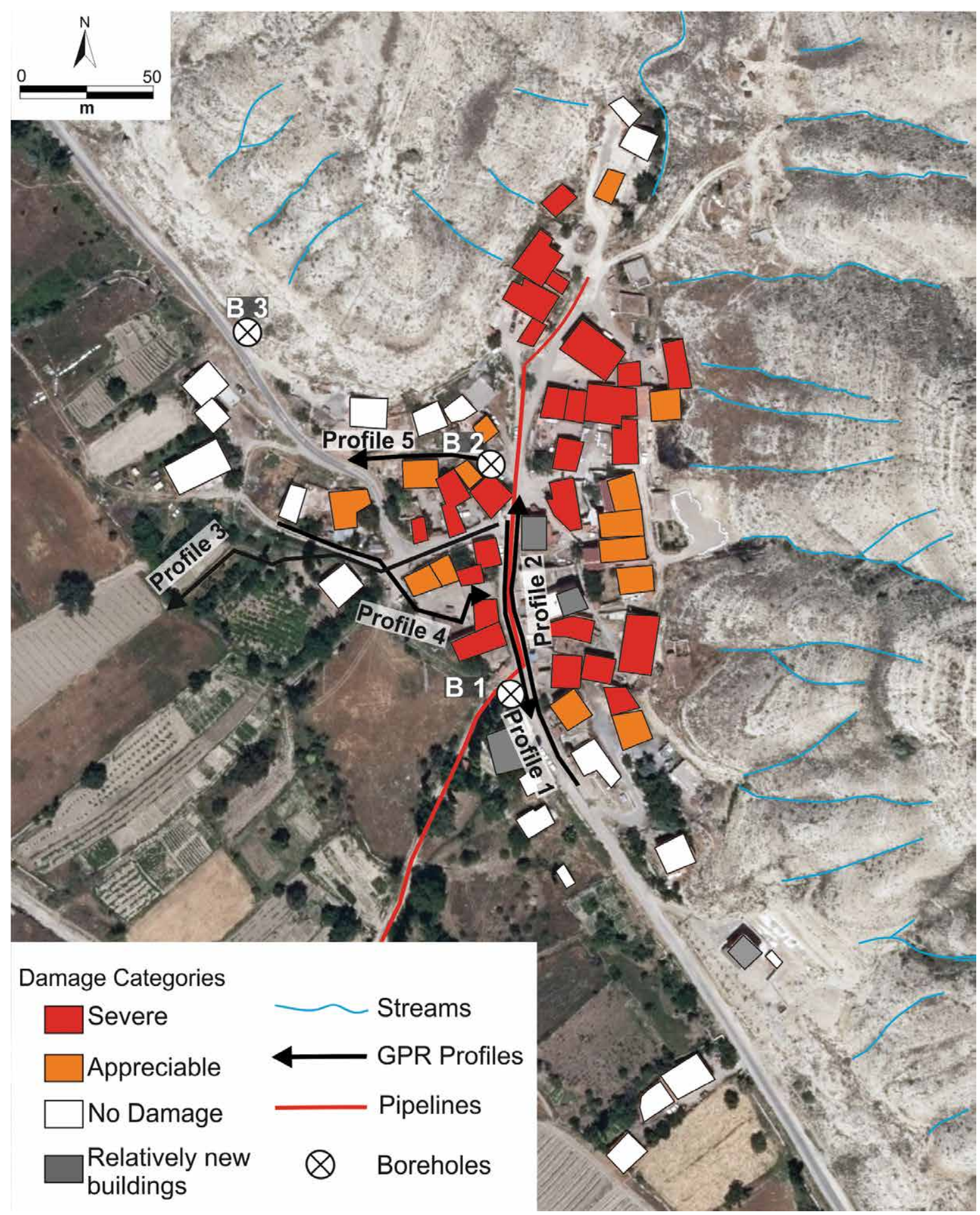

Figure 5. Map of damage distribution in March 2017 showing location of boreholes, GPR profiles (Özçelik et al. 2016) and pipeline. tected in these profiles.

Boreholes 1 and 2 were drilled in the valley bottom of Inandık village (Fig. 5). Both boreholes show dissolution cavities in the gypsum (Fig. 6c). According to this data, the thickness of the alluvium is $1.5-3$ $\mathrm{m}$. Borehole 3 was drilled on the bedrock northwest of the village. No void was detected in its log 3 (Özçelik et al., 2016).

\section{Discussion}

\section{Sinkholes}

$S$ e $v$ e $n$ sinkholes are clustered on the terrace surface in the study area due to geomorphological and hydrologic factors. There is a relationship between the development of fluvial systems on a karst massif and the generation of sinkholes (Benito et al., 1998, 2000; 

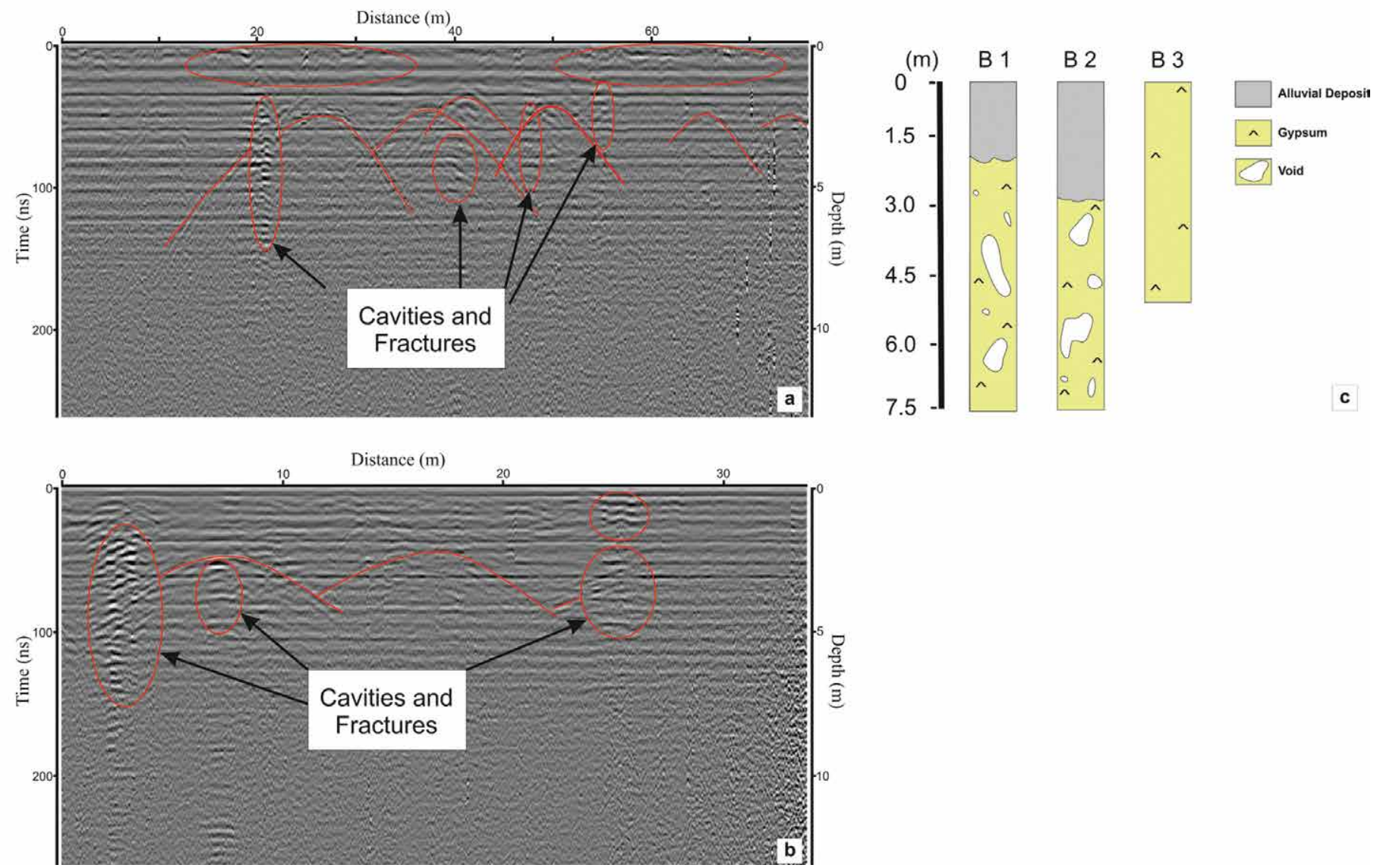

Figure 6. GPR profiles of (a) profile 1, and (b) profile 5. (c) Log of boreholes drilled in Inandık village (modified from Özçelik et al. 2016).

Doğan, 2005; Guerrero et al., 2008, 2013; Gutiérrez and Cooper, 2013; Gutiérrez, 2014). The incision of rivers forms a deep vadose zone and lower water table (Ortega et al., 2013). It also accelerates cavity development and internal erosion and gives rise to diminished thickness and mechanical strength of the cavity roofs.

The current geomorphological features of the area were formed when Inandık stream and its tributaries eroded the surface of the valley, giving rise to a terrace in which the gypsum cavities were less covered (Fig. 7). The streams incised the valley by more than $15 \mathrm{~m}$ forming a new, lower base level and a higher hydraulic gradient, thus accelerating cavity development, subsurface erosion, and upward migration of the cover deposits.

There was no sinkhole formation on the adjacent heights of the terrace (Fig. 7) because they have a relatively thick cavity roof. In the valley bottom, the alluvial cover is thicker and the hydraulic gradient is lower; therefore, only sinkholes $1 \mathrm{~m}$ wide or smaller were formed there.

The sinkholes we detected are due solely to natural processes. Human-induced factors such as the pumping up of groundwater or extra water input into the ground were not detected. Moreover, most sinkholes were formed before 1953 (Table 1) when human influence was far less. It is plausible that other sinkholes occurred in the Quaternary, but these would have been buried later by the stream system.

\section{Subsidence in the village}

In-house service and sewer pipes are more likely to cause subsidence (Fleury, 2009; Parise, 2015) and pipeline breakage gives rise to damage in karst areas (Jassim et al., 1997; Gutiérrez and Cooper, 2002; Cooper et al., 2011; Cooper and Gutiérrez, 2013; Parise et al., 2015). In Inandık, ground subsidence must have caused the abnormally frequent breaking of pipes, which caused extra water input into the ground and triggered progressive subsidence of the land, creating a vicious circle. Moreover, some household waste water flows directly into the ground, which causes localized subsidence. All these processes give rise to dissolution and the formation of new cavities (Fig. 8).

According to the GPR profiles, cavities were detected only on profiles 1 (Fig. 6a) and 5 (Fig. 6b). However, the distribution map of subsidence damage (Fig. 5) shows that it affects a wider area than the GPR result indicates. It is known that the clay content of alluvium is an obstacle influencing the depth that GPR systems can reach (Schrott and Sass, 2008; Pueyo-Anchuela et al., 2009; Nouioua et al., 2013); therefore, the penetration of the GPR system was not satis- 


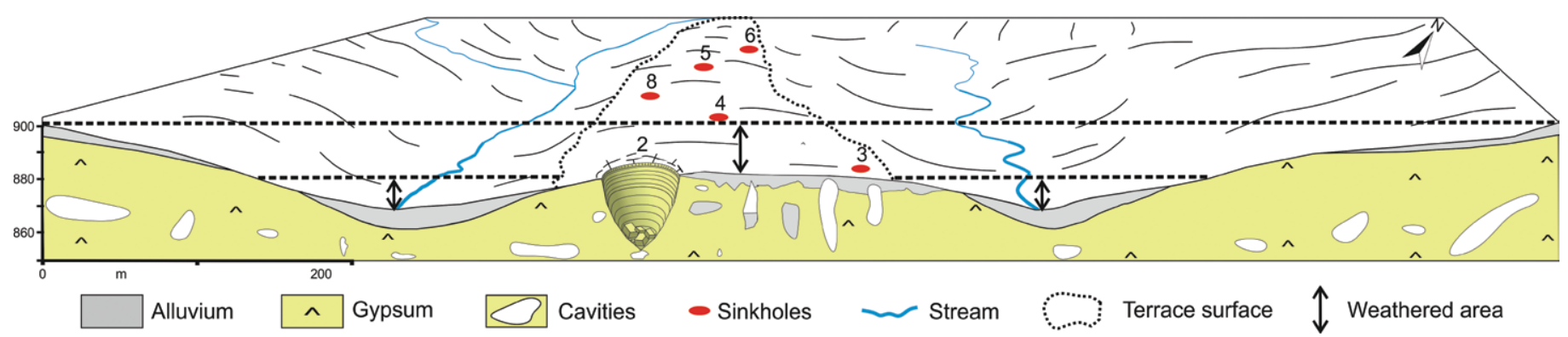

Figure 7. 3D Geomorphological scheme (A-B) of Inandık stream showing flow level differences and sinkholes (See Figure 1c).

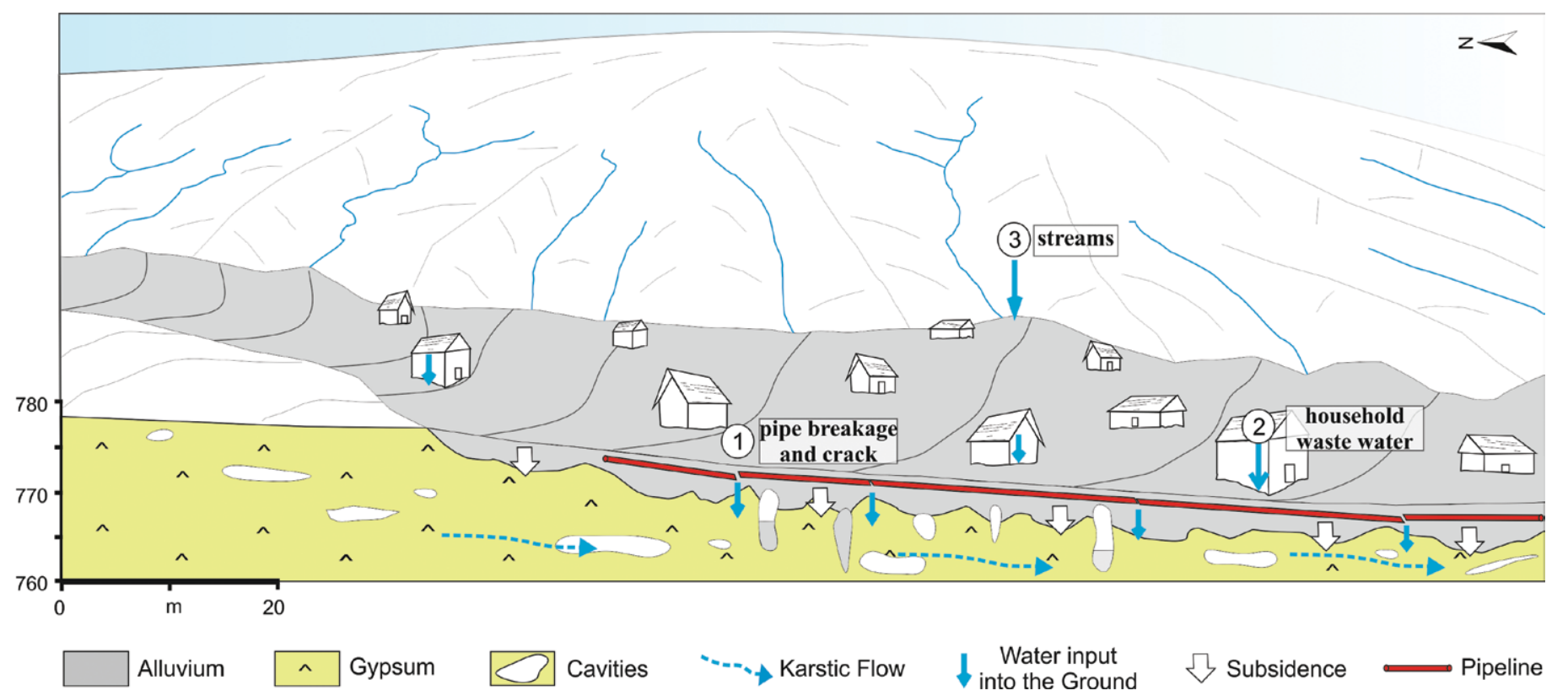

Figure 8. Cross-section of pipeline (Fig. 5) and 3D geomorphological scheme of Inandık village depicting effect of subsidence.

factory in several studies (Gutiérrez et al., 2011; Margiotta et al., 2012, 2016; Carbonel et al., 2014, 2015; Rodriguez, 2014; Zini et al., 2015). This limit to GPR penetration is probably the case in Inandık, explaining the apparent inconsistency between the results of profiles 1 and 2, which are on the same line and only two meters apart (Fig. 5). Therefore, the usefulness of GPR surveying for identification of possible sinkholes in alluvial karst areas may be limited due to high electrical conductivity values, whilst it remains appropriate for bare karst areas.

The Inandık settlement is situated on 1.5-3 m alluvial deposits overlying a layer of gypsum, according to the boreholes (Fig. 6c). These thin alluvial deposits caused the village to be favorable for subsidence. On the other hand, the main valley has relatively-thick alluvial deposits SW of the village and buildings here show no damage (Fig. 5). The center of the village is subject to greater internal erosion because of its thin alluvial cover.

From the borehole logs, registers, and GPR profiles 1 and 5, similar cavities to those in outcrops (Fig. 3) were deduced. They are very superficial, which explains the damage to single-story homes with smaller loads on their foundations.

\section{Conclusion}

The aim of this study was to examine the subsidence problems of Inandık village in Turkey. Gypsum dissolution is evident in the entire fluvial system of Inandık stream. A series of ground collapses was identified on a terrace located upstream from the settlement. On this terrace, the surface is more-than-usually prone to the formation of sinkholes because of the reduced thickness and mechanical strength of the cavity roof and the thinness of the alluvial deposits; hence, seven large sinkholes were formed.

In the settlement, in addition to circumstances favorable to the karst phenomena with houses located in an area subject to underground water flow and the presence of cavities (Fig. 3), the process has been accelerated by human action when a water distribution network was installed in homes in 2007, which increased water usage, and a new 
sewage system was constructed in 2012. The pipes of these networks cracked and broke frequently and some homes still discharge water directly underground. This leakage has resulted in enhanced subsidence and progressive damage to buildings in the last decade. In consequence, the severity of the damage led to the decision to re-locate the village.

It is hoped that the results of this study will contribute to increasing the awareness among decision-makers who need to consider the karst system of the area they are responsible for in order to take preventative measures. To reduce or prevent hazards related to subsidence in a settlement which overlies gypsum, such as Inandık, extra water input to the subsurface should be minimized (Parise, 2015) and flexible pipes with a telescopic joint should be used to alleviate cracks and breakage.

\section{Acknowledgments}

We thank Uğur Doğan for his useful suggestions. We also thank Salih Karaca, Muhammet Öksüz. and Ayla Deniz for their assistance during the field work, and Mr. Graham $\mathrm{H}$. Lee for his contribution to correction of the English in the manuscript. This paper has benefited from the valuable comments of the two anonymous reviewers, for which we are grateful.

\section{References}

Alagöz, C., 1967, Gypsum karst phenomena in Sivas area and its east: Ankara, Ankara University Faculty of Languages History and Geography Publication no. $175,126 \mathrm{p}$.

Alexander, D., 1986, Landslide damage to buildings: Environmental Geology and Water Science., v. 8, no. 3, p. $147-151$.

Basso, A., Bruno, E. Parise, M., and Pepe, M., 2013, Morphometric analysis of sinkholes in a karst coastal area of southern Apulia (Italy): Environmental Earth Sciences, v. 70, no. 6, p. 2545-2559. https://doi.org/10.1007/s12665-013-2297-z.

Benito, G., Delcampo, P.P., Gutiérrezelorza, M., and Sancho, C., 1995, Natural and human-induced sinkholes in gypsum terrain and associated environmental-problems in N Spain: Environmental Geology, v. 25, p, 156--164. https://doi.org/10.1007/BF00768545.

Benito, G., Gutiérrez, F., Pérez-González, A., and Machado, M.J., 2000, Geomorphological and sedimentological features in Quaternary fluvial systems affected by solution-induced subsidence (Ebro Basin, NE-Spain): Geomorphology, v. 33, p. 209-224. https://doi.org/10.1016/S0169$555 X(99) 00124-5$

Benito, G., Pérez-González, A., Gutiérrez, F., and Machado, M., 1998, River response to Quaternary subsidence due to evaporite solution (Gállego River, Ebro Basin, Spain): Geomorphology, v. 22, p. 243-263. https://doi.org/10.1016/S0169-555X(97)00088-3.

Calcaterra, D., and Parise, M., 2001, The contribution of historical information in the assessment of landslide hazard, in Glade, T., Albini, P., and Francés, F., eds., The Use of Historical Data in Natural Hazard Assessments: Dordrecht, Springer Netherlands, p. 201-216. https://doi. org/10.1007/978-94-017-3490-5_15.

Calligaris, C., Devoto, S., Galve, J. P., Zini, L., and Pérez-Peña, J. V., 2017, Integration of multi-criteria and nearest neighbour analysis with kernel density functions for improving sinkhole susceptibility models: the case study of Enemonzo (NE Italy): International Journal of Speleology, v. 46, no. 2, p. 191-204. https://doi.org/10.5038/1827-806X.46.2.2099.

Carbonel, D., Rodríguez-Tribaldos, V., Gutiérrez, F., Galve, J.P., Guerrero, J., Zarroca, M., Roqué, C., Linares, R., McCalpin, J.P., and Acosta, E., 2015, Investigating a damaging buried sinkhole cluster in an urban area (Zaragoza city, NE Spain) integrating multiple techniques: Geomorphological surveys, DInSAR, DEMs, GPR, ERT, and trenching: Geomorphology, v. 229, p. 3-16. https://doi.org/10.1016/j.geomorph.2014.02.007.

Carbonel, D., Rodríguez- Tribaldos, V., Gutiérrez, F., McCalpin, J., Linares, R., Roqué, C., Zarroca, M., Guerrero, J., and Sasowsky, I., 2014, Evaluation of trenching, ground penetrating radar (GPR) and electrical resistivity tomography (ERT) for sinkhole characterization: Earth Surface Processes and Landforms, v. 39, no. 2, p. 214-227 https://doi.org/10.1002/esp.3440.

Chiocchio, C., lovine, G., and Parise, M., 1997, A proposal for surveying and classifying landslide damage to buildings in urban areas, in Marinos, P.G., Koukis, G., Tsiambaos, G. and Stournaras, G., eds., Proceedings of the International Symposium on Engineering Geology and the Environment, Athens, June 23-27, 1997, v. 1, p. 553-558.

Cooper, A.H., 1998, Subsidence hazards caused by the dissolution of Permian gypsum in England: geology, investigation and remediation: Geological Society, London, Engineering Geology Special Publications, v. 15, p. 265-275. https://doi.org/10.1144/gsl.eng.1998.015.01.27.

Cooper, A.H., 2008, The classification, recording, databasing and use of information about building damage caused by subsidence and landslides: Quarterly Journal of Engineering Geology and Hydrogeology, v. 41, no. 3, p. 409-424. https://doi.org/10.1144/1470-9236/07-223.

Cooper, A.H., and Calow, R.C., 1998, Avoiding gypsum geohazards: guidance for planning and construction, Nottingham: British Geological Survey Technical Report WC/98/5, $57 \mathrm{p}$.

Cooper, A.H., Farrant, A.R., and Price, S.J., 2011, The use of karst geomorphology for planning, hazard avoidance and development in Great Britain: Geomorphology, v. 134, p. 118-131. https://doi.org/10.1016/j.geomorph.2011.06.004.

Cooper, A.H., and Gutiérrez, F., 2013, Dealing with gypsum karst problems: hazards, environmental issues, and planning, in Shroder, J., and Frumkin, A., eds., Treatise on Geomorphology: San Diego, Academic Press, v.6, p. 451-462.

Cooper, A.H., and Saunders, J.M., 2002, Road and bridge construction across gypsum karst in England: Engineering Geology, v. 65, p. $217-223$. https://doi.org/10.1016/S0013-7952(01)00131-4.

De Waele, J., Piccini, L., Columbu, A., Madonia, G., Vattano, M., Calligaris, C., D’Angeli, I., Parise, M., Chiesi, M., and Sivelli, M., 2017, Evaporite karst in Italy: a review: International Journal of Speleology, v. 46, no. 2, p. 137-168. https://doi.org/10.5038/1827-806X.46.2.2107.

Delle Rose, M., Federico, A., and Parise, M., 2004, Sinkhole genesis and evolution in Apulia, and their interrelations with the anthropogenic environment: Natural Hazards and Earth System Sciences, v. 4, p. 747-755. https://doi.org/10.5194/nhess-4-747-2004.

Delle Rose, M., and Parise, M., 2002, Karst subsidence in south-central Apulia, southern Italy: International Journal of Speleology, v. 31, no. 1-4, p. 181-199.

Del Prete, S., lovine, G., Parise, M., and Santo, A., 2010, Origin and distribution of different types of sinkholes in the plain areas of Southern Italy: Geodinamica Acta, v. 23, no. 1-3, p. 113-127. https://doi.org/10.3166/ga.23.113-127.

Doğan, U., 2002, Subsidence dolines formed by gypsum karstification at the east of Çankırı (in Turkish): Gazi University Journal of Gazi Educational Faculty, v. 22, p. 67-82. 
Doğan, U., 2005, Land subsidence and caprock dolines caused by subsurface gypsum dissolution and the effect of subsidence on the fluvial system in the Upper Tigris Basin (between Bismil-Batman, Turkey): Geomorphology, v. 71, p. 389-401. https://doi.org/10.1016/j.geomorph.2005.04.010.

Doğan, U., and Özel, S., 2005, Gypsum karst and its evolution east of Hafik (Sivas, Turkey): Geomorphology, v. 71, p. 373-388. https://doi. org/10.1016/j.geomorph.2005.04.009.

Doğan, U., and Yeşilyurt, S., 2004, Gypsum karst south of İmranlı, Sivas, Turkey: Cave and Karst Science, v. 31, no. 1, p. 7-14.

Festa, V., Fiore, A., Parise, M., and Siniscalchi, A., 2012, Sinkhole evolution in the Apulian karst of southern Italy: a case study, with some considerations on sinkhole hazards: Journal of Cave and Karst Studies, v. 74, no. 2, p. 137-147. https://doi.org/10.4311/2011jcks0211.

Fleury, S., 2009, Land use policy and practice on karst terrains: Living on limestone: Netherlands, Springer, 187 p. https://doi 10.1007/978-14020-9670-9.

Guerrero, J., Gutiérrez, F., and Galve, J.P., 2013, Large depressions, thickened terraces, and gravitational deformation in the Ebro River valley (Zaragoza area, NE Spain): Evidence of glauberite and halite interstratal karstification: Geomorphology, v. 196, p. 162-176. https://doi. org/10.1016/j.geomorph.2012.06.024.

Guerrero, J., Gutiérrez, F., and Lucha, P., 2008, Impact of halite dissolution subsidence on Quaternary fluvial terrace development: Case study of the Huerva River, Ebro Basin, NE Spain: Geomorphology, v. 100, p. 164-179. https://doi.org/10.1016/j.geomorph.2007.04.040.

Günay, G., 2002, Gypsum karst, Sivas, Turkey: Environmental Geology, v. 42, p. 387-398. https://doi.org/10.1007/s00254-002-0532-0.

Gutiérrez, F., 2014, Evaporite karst in Calatayud, Iberian Chain, in Gutiérrez, F., Gutiérrez, M., eds., Landscapes and Landforms of Spain: Dordrecht, Springer Netherlands, p. 111-125. https://doi:10.1007/978-94-017-8628-7_9.

Gutiérrez, F., 2016, Sinkhole hazards, in Cutter, S.L., ed., Oxford Research Encyclopedia of Natural Hazard Science: Oxford, Oxford University Press, p. 1-92. https://doi:10.1093/acrefore/9780199389407.013.40.

Gutiérrez, F., and Cooper, A.H., 2002, Evaporite dissolution subsidence in the historical city of Calatayud, Spain: damage appraisal and prevention: Natural Hazards, v. 25, p. 259-288. https://doi.org/10.1023/A:1014807901461.

Gutiérrez, F., and Cooper, A.H., 2013, Surface morphology of gypsum karst, in Shroder, J., ed. in chief, Frumkin, A., ed., Treatise on geomorphology: San Diego, Academic Press, v. 6, p. 451-462.

Gutiérrez, F., Cooper, A.H., and Johnson K.S., 2008, Identification, prediction, and mitigation of sinkhole hazards in evaporite karst areas: Environmental Geology, v. 53, p. 1007-1022. https://doi:10.1007/s00254-007-0728-4.

Gutiérrez, F., Fabregat, I., Roqué, C., Carbonel, D., Zarroca, M., Linares, R., Yechieli Y., García-Arnay, A., and Sevil, J., 2019, Sinkholes in hypogene versus epigene karst systems, illustrated with the hypogene gypsum karst of the Sant Miquel de Campmajor Valley, NE Spain: Geomorphology, v. 328, p. 57-78. https://doi.org/10.1016/j.geomorph.2018.12.003.

Gutiérrez, F., Parise, M., De Waele, J., and Jourde, H., 2014, A review on natural and human-induced geohazards and impacts in karst: Earth-Science Reviews, v. 138 p. 61-88. https://doi:10.1016/j.earscirev.2014.08.002.

Iovine, G., Parise, M., and Trocino, A., 2010, Instability phenomena in the evaporite karst of Calabria, Southern Italy: Zeitschrift für Geomorphologie, Supplementary Issues, v. 54, no. 2, p. 153-178. https://doi.org/10.1127/0372-8854/2010/0054S2-0009

Jassim, S.Z., Jibril, A.S., and Numan, N.M., 1997, Gypsum karstification in the middle Miocene Fatha Formation, Mosul area, northern Iraq: Geomorphology, v. 18, p. 137-149. https://doi.org/10.1016/S0169-555X(96)00018-9.

Johnson, K.S., 2005, Subsidence hazards due to evaporite dissolution in the United States: Environmental Geology, v. 48, p. 395-409. https:// doi:10.1007/s00254-005-1283-5.

Karacan, E., and YIImaz, I., 1997, Collapse dolines in Miocene gypsum: an example from SW Sivas (Turkey): Environmental Geology, v. 29, p. 263-266. https://doi.org/10.1007/s002540050125.

Karadenizli, L., 2011, Oligocene to Pliocene palaeogeographic evolution of the Çankırı-Çorum Basin, central Anatolia, Turkey: Sedimentary Geology, v. 237, p. 1-29. https://doi.org/10.1016/j.sedgeo.2011.01.008.

Keskin, İ., and Yılmaz, I., 2016, Morphometric and geological features of karstic depressions in gypsum (Sivas, Turkey): Environmental Earth Science v. 75, p. 1040-1054. https://doi.org/10.1007/s12665-016-5845-5.

Klimchouk, A., and Andrejchuk, V., 1996, Breakdown development in cover beds, and landscape features induced by intrastratal gypsum karst: International Journal of Speleology, v. 25, no. 3, p. 127-144. http://dx.doi.org/10.5038/1827-806X.25.3.10.

Klimchouk, A., and Andrejchuk, V., 2002, Karst breakdown mechanisms from observations in the gypsum caves of the Western Ukraine: implications for subsidence hazard assessment: International Journal of Speleology, v. 31, p. 55-88. http://dx.doi.org/10.5038/1827-806X.31.1.4.

Klimchouk, A., Cucchi, F., Calaforra, J.M., Aksem, S., Finocchiaro, F., and Forti, P., 1996, Dissolution of gypsum from field observations, in Klimchouk, A., Lowe, D., Cooper, A., and Sauro, U., eds., Gypsum karst of the world: International Journal of Speleology, v. 25, no. 3-4, p. 37-48. http://dx.doi.org/10.5038/1827-806X.25.3.3.

Koutepov, V.M., Mironov, O.K., and Tolmachev, V.V., 2008, Assessment of suffosion-related hazards in karst areas using GIS technology: Environmental Geology, v. 54, p. 957-962. http://doi:10.1007/s00254-007-0888-2.

Margiotta, S., Negri, S., Parise, M., and Quarta, T. A. M., 2016, Karst geosites at risk of collapse: the sinkholes at Nociglia (Apulia, SE Italy): Environmental Earth Sciences, v. 75, no. 1, p. 8. https://doi.org/10.1007/s12665-015-4848-y.

Margiotta, S., Negri, S., Parise, M., and Valloni, R., 2012, Mapping the susceptibility to sinkholes in coastal areas, based on stratigraphy, geomorphology and geophysics: Natural Hazards, v. 62, no. 2, p. 657-676. https://doi.org/10.1007/s11069-012-0100-1.

Martinez, J.D., Johnson, K.S., and Neal, J.T., 1998, Sinkholes in evaporite rocks: American Scientist, v. 86, p. 38-51. http:// doi:10.1511/1998.17.909.

National Coal Board, 1975, Subsidence Engineers'Handbook: National Coal Board Mining Department.

Nouioua, I., Rouabhia, A., Fehdi, C., Boukelloul, M., Gadri, L., Chabou, D., and Mouici, R., 2013, The application of GPR and electrical resistivity tomography as useful tools in detection of sinkholes in the Cheria Basin (northeast of Algeria): Environmental Earth Science, v. 68, $p$. 1661-1672. https://doi.org/10.1007/s12665-012-1859-9.

Ortega, A.I., Benito-Calvo, A., Pérez-González, A., Martín-Merino, M.A., Pérez-Martínez, R., Parés, J.M., Aramburu, A., Arsuaga, J.L., Bermúdez de Castro, J.M., and Carbonell, E., 2013, Evolution of multilevel caves in the Sierra de Atapuerca (Burgos, Spain) and its relation to human occupation: Geomorphology, v. 196, p. 122-137. https://doi.org/10.1016/j.geomorph.2012.05.031.

Özçelik, A., Yiğit, A.E., Işık, B., Arıtürk, M.A., Özen, Ö., and Büyükurvayli, B., 2016, Determination of karstic cavities and sinkholes by geophysical methods: Inandık Village Application, in Keskin, İ., and Göloğlu, C., eds., Proceedings of International Symposium on Natural Hazards and Hazard Management: Karabük, p. 543-549. (in Turkish)

Pando, L., Pulgar, J.A., and Gutiérrez-Claverol, M., 2012, A case of man-induced ground subsidence and building settlement related to karstified gypsum (Oviedo, NW Spain): Environmental Earth Science, v. 68, p. 507-519. https://doi:10.1007/s12665-012-1755-3. 
Parise, M., 2010, Hazards in karst, in Bonacci, O., ed., Proceedings of International Interdiscplinary Scientific Conference, Sustainability of the Karst Environment, Dinaric Karst and Other Karst Regions: International Interdisciplinary Scientific Conference, Plitvice Lakes, Croatia, September 23-26, 2009, IHP-UNESCO, Series on Groundwater, no. 2, p. 155-162.

Parise, M., 2015, A procedure for evaluating the susceptibility to natural and anthropogenic sinkholes: Georisk, v. 9, no. 4, p. 272-285. https://doi $: 10.1080 / 17499518.2015 .1045002$.

Parise, M., De Waele, J., and Gutiérrez, F., 2009, Current perspectives on the environmental impacts and hazards in karst: Environmental Geology, v. 58, no. 2, p. 235-237. https://doi:10.1007/s00254-008-1608-2.

Parise, M., Qiriazi, P., and Sala, S., 2004, Natural and anthropogenic hazards in karst areas of Albania: Natural Hazards and Earth System Science, v. 4, no. 4, p. 569-581.

Parise, M., Ravbar, N., Živanović, V., Mikszewski, A., Kresic, N., Mádl-Szőnyi, J., and Kukurić, N., 2015, Hazards in Karst and Managing Water Resources Quality, in Stevanović, Z., ed., Karst Aquifers-Characterization and Engineering: Cham, Springer International Publishing, p. 601-687. https://doi.org/10.1007/978-3-319-12850-4_17.

Parise, M., and Trocino, A., 2016, Gypsum Karst in the Crotone Province (Calabria, Southern Italy): Acta Carsologica, v. 34, no. 2, p. $369-382$. https://doi.org/10.3986/ac.v34i2.264.

Parise, M., and Wasowski, J., 1999, Landslide activity maps for landslide hazard evaluation: three case studies from southern Italy: Natural Hazards, v. 20, no. 2, p. 159-183. https://doi.org/10.1023/A:1008045127240.

Paukštys, B., Cooper, A.H., and Arustiene, J., 1999, Planning for gypsum geohazards in Lithuania and England: Engineering Geology, v. 52, no. 1, p. 93-103. https://doi.org/10.1016/S0013-7952(98)00061-1.

Pisano, L., Zumpano, V., Malek, Ž., Rosskopf, C.M., and Parise, M., 2017, Variations in the susceptibility to landslides, as a consequence of land cover changes: A look to the past, and another towards the future: Science of The Total Environment, v. 601-602, p. 1147-1159. https://doi. org/10.1016/j.scitotenv.2017.05.231.

Pueyo-Anchuela Ó., Casas-Sainz, A., Soriano, M., and Pocoví-Juan, A., 2009, Mapping subsurface karst features with GPR: results and limitations: Environmental Geology, v. 58, p. 391-399. https://doi.org/10.1007/s00254-008-1603-7.

Rodriguez, V., Gutiérrez, F., Green, A. G., Carbonel, D., Horstmeyer, H., And Schmelzbach, C., 2014, Characterizing Sagging and Collapse Sinkholes In A Mantled Karst By Means Of Ground Penetrating Radar (GPR) Characterizing Mantled Karst Sinkholes By GPR: Environmental And Engineering Geoscience, v. 20, no. 2, p. 109-132.

Sauro, U., 1996, Geomorphological aspects of gypsum karst areas with special emphasis on exposed karst: International Journal of Speleology, v. 25 , no. 3-4, p. 105-114. http://dx.doi.org/10.5038/1827-806X.25.3.8.

Schrott, L., and Sass, O., 2008, Application of field geophysics in geomorphology: Advances and limitations exemplified by case studies: Geomorphology, v. 93, no. 1, p. 55-73. https://doi.org/10.1016/j.geomorph.2006.12.024.

Sönmez, I.., 2014, Glauberite-halite association in bozkır formation (Pliocene, Çankırı-Çorum Basin, Central Anatolia, Turkey): Bulletin of the Mineral Research and Exploration, v. 149. p. 155-177. http://dx.doi.org/10.19111/bmre.68068.

Thierry, P., Prunier-Leparmentier, A.M., Lembezat, C., Vanoudheusden, E., and Vernoux, J.F., 2009, 3D geological modelling at urban scale and mapping of ground movement susceptibility from gypsum dissolution: The Paris example (France): Engineering Geology, v. 105, no. 1, p. 51-64. https://doi.org/10.1016/j.enggeo.2008.12.010.

Waltham, T., 2002, Gypsum karst near Sivas, Turkey: Cave and Karst Science, v. 29, p. 39-44.

Waltham, T., Bell, F., and Culshaw, M., 2005, Sinkholes and Subsidence. Karst and Cavernous Rocks in Engineering and Construction: Dordrecht, Springer, $382 \mathrm{p}$.

Yilmaz, I., 2007, GIS based susceptibility mapping of karst depression in gypsum: A case study from Sivas basin (Turkey). Engineering Geology, v. 90, p. 89-103. http://doi:10.1016/j.enggeo.2006.12.004.

Zini, L., Calligaris, C., Forte, E., Petronio, L., Zavagno, E., Boccali, C., and Cucchi, F., 2015, A multidisciplinary approach in sinkhole analysis: The Quinis village case study (NE-Italy): Engineering Geology, v. 197, p. 132-144. https://doi.org/10.1016/j.enggeo.2015.07.004. 